JARES, Vol. 2 No. 2 September, 2017; p-ISSN: 2502-826X; e-ISSN: 2503-1163

Copyrights@ Balitar Islamic University, Blitar, Indonesia; Http://jares.unisbablitar.ejournal.web.id

Citation: Prayudhi, Luhur Aditya . 2017. Analysis of Farm in Pineapple (Ananas comulus (L.) Merr)

in Sempu Village, District Ngancar, Kediri). JARES, (2017), 2(2): 10-18

\title{
ANALYSIS OF FARM IN PINEAPPLE (Ananas comulus (L.) Merr) IN SEMPU VILLAGE, DISTRICT NGANCAR, KEDIRI
}

\author{
Luhur Aditya Prayudhi \\ Balitar Islamic University \\ Email: luhuradityaprayudhi@gmail.com
}

\begin{abstract}
Abstrack
The agricultural sector plays an important role in national development. The area of cultivated land or planting area and harvest of Indonesian fruits on average is relatively small. Pineapple is a type of fruit found in the tropics and consumed in a lot of fresh. One of the pineapple producing areas in Kediri Regency is in Ngancar District, including Sempu Village. The purpose of this study is to determine the expenditure and income of pineapple farmers in Sempu Village District Ngancar Kediri and to determine the feasibility of pineapple farming in Sempu Village District Ngancar Kediri. For pineapple farming requires a variable cost consisting of expenses consumed and labor costs Total variable costs for land area of 0.5 Ha Rp 15.312.000 and land area $1 \mathrm{Ha} \mathrm{Rp} \mathrm{30.655.000.} \mathrm{For} \mathrm{fixed}$ cost of pineapple farm consist of land rent, capital interest can be known fixed cost for land

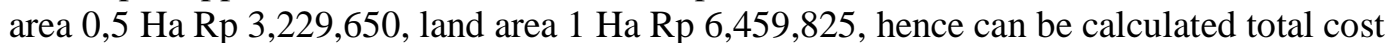
in pineapple farm for land with wide area $0.5 \mathrm{Ha}$ of $\mathrm{Rp} 18,542,180$ and pineapple farming with a land area of $1 \mathrm{Ha}$ of $\mathrm{Rp} 37,114,825$. The sale results obtained by pineapple farmers selling price according to the quality of pineapple fruit, for the land area of $0.5 \mathrm{Ha}$ obtained

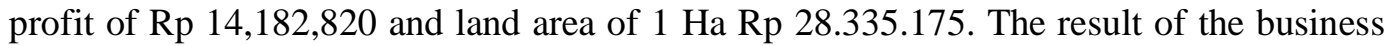
feasibility test of 0.5 ha and 1 ha is not the same for 0.5 ha yield 1.7648 . While for 1 ha $\mathrm{R}$ / C ratio produces 1.7634 . For both patterns are equally good and worth developing.
\end{abstract}

\section{Keywords: Farming, feasibility}

Received: 20 August, 2017; Accepter: 10 September, 2017

\section{INTRODUCTION}

Indonesia is one of the developing countries with the agricultural sector as the source of livelihood of the majority of its population, meaning that most of the population depends on agriculture sector. Where the use of land areas in Indonesia is largely designated as agricultural land (Husodo, 2004)

The agricultural sector plays an important role in national development. In addition to providing food for the entire national population, this sector also contributes foreign exchange and provides employment opportunities and raw materials for industry.

The area of cultivated land or planting area and harvest of Indonesian fruits on average is relatively small. Seasonal nature is too big, usahtani management is very simple and impressed potluck because more as a side business. As a result of its production and productivity is very small and very diverse from one place to another. (Arifin, 2001).

Pineapple is a type of fruit found in the tropics and consumed in a lot of fresh. Pineapple fruit is preferred because it tastes good and the aroma is typical and contains vitamin C. Pineapple fruit can be processed into various delicious foods such as canned fruit, sweets, jelly, 
fruit juice and some other products. Other parts of pineapple plants such as leather can be used to make paper. Pineapple is rich in minerals that the body needs such as potassium, chlorine, sodium, phosphorus, magnesium, sulfur, calcium, iron and iodine. The vitamins present in the pineapple are vitamins A, B, C and E. The presence of bromelani iron in non-cooked pineapple juice makes pineapple a good anti-inflammatory agent (Nainggolan, 2006)

One that is inherent in the people of Indonesia is a little capital. Whereas capital is very important in supporting the increase of production and living standard of society. Lack of capital will affect income. In a farm requires working capital where this capital has a very big role in pengadan production facilities and wages of labor.

Land is a key factor in agricultural business. The scale of business is also determined by the extent of land to be cultivated. The production process runs smoothly and profitably with other factor notes can be overcome. Capital adequacy affects accuracy in the use of inputs. Lack of capital results in low yields. (Daniel, 2001)

One of the pineapple producing areas in Kediri Regency is in Ngancar District, including Sempu Village. In the development effort of pineapple in District Ngancar very support pembudidayaannya. Types of pineapple fruit cultivated in the area is the type of pineapple queen, cone-shaped conical fruit until cylindrical, reddish yellow flesh, sweet taste. This is because other types of pineapple such as pineapple bogor is still difficult to obtain and seedlings are expensive, while the pineapple queen seedlings are easy to get and cheaper.

Capital adequacy affects the timeliness and accuracy of the dosage in input use. Lack of capital causes the received income to be given so that the risk of failure or low causes a lack of income for pineapple growers. Farm laborers can be obtained from family and non-family labor. Out-of-family labor is obtained by way of wages. Area of land as a place of pineapple cultivation also affect the income level of pineapple farmers in the village of Pojok which is a village as a producer of pineapple in District Ngancar

Based on this background, the researcher took the research entitled "Analysis of Factors Affecting Peanut Farmer's Income (Ananas Comosus (L.,) merr) in Kecamatan Ngancar Kediri". Based on the background that has been described above it can be covered in the formulation of the problem as follows:

1. What is the expenditure and income of pineapple farming in Sempu Village, Ngancar District, Kediri District?

2. Is pineapple farming feasible to be developed by pineapple farmers in the village of Sempu District Ngancar Kediri?

\section{Research Purposes}

1. To find out the expenditure and income of pineapple farmer in Sempu Village District Ngancar Kediri Regency.

2. To determine the feasibility of pineapple farming in Sempu Village District Ngancar Kediri

\section{RESEARCH METHODS}

\section{Location And Time Research}

Method of taking the research area is done purposively (purposive) that is in Sempu Village, District of Ngancar, Kediri Regency. The selection of research sites is done deliberately 
based on the consideration that the area is one of the pineapple producing areas. Data collection was conducted in October 2017.

\section{Method of collecting data}

The data collected consist of primary data and secondary data. Primary data is or obtained directly from interviews with sample farmers using a list of questionnaires that have been prepared first. While secondary data is data obtained from various institutions or agencies and coupled with literature related to research (Soekartawi, 2002)

\section{Data analysis method}

CalculationCost, Receipts, Revenue

\section{Total Cost}

To calculate the costs incurred by farmers in the production process (in this case include fixed costs and variable costs) used the formula:

$$
\mathrm{TC}=\mathrm{TFC}+\mathrm{TVC}
$$

Where:

TC (Total Cost

TFC (Total Fixed Cost)
: Total cost incurred by farmers $(\mathrm{Rp})$

: Total fixed costs incurred by farmers $(\mathrm{Rp})$

TVC (Total Variable Cost) : Total variable cost incurred by farmers (Rp)

\section{Calculation of Revenue}

To calculate the acceptance of farming can be calculated by the formula:

Where:

$$
\mathrm{TR}=\mathrm{P} \text { X Q }
$$

$$
\begin{array}{ll}
\text { TR (Total Revenue) } & \text { : Total revenue }(\mathrm{Rp}) \\
\text { P (Price) } & \text { : Product Price }(\mathrm{Rp}) \\
\text { Q (Quantity) } & \text { : Total production }(\mathrm{Kg})
\end{array}
$$

\section{Income Calculation}

Revenue / Profit farming is the difference between the total revenue with the total cost, makadirumuskan:

$$
\pi=\mathrm{TR}-\mathrm{TC}
$$

Where:

$\Pi$ : Revenue / profit (Rp)

TR : Total Reception (Rp)

TC : Total Cost $(\mathrm{Rp})$

\section{Business Feasibility Analysis}

This efficiency analysis aims to determine whether the yield of brown sugar farming is efficient or not, then between the analysis of R / C Ratio (Return Cost Ratio), where R / C Ratio is the ratio between revenue with production.

With the following formula (Soekartawi, 1986)

Where :

$$
\mathrm{R} / \mathrm{C} \text { Ratio }=\mathrm{TR} / \mathrm{TC}
$$

$\mathrm{TR}=$ Total Revenue 
$\mathrm{TC}=$ Total Cost

Research Rules

1. $\mathrm{R} / \mathrm{C}<1$ where the farm is not feasible to make farming / efficient

2. $\mathrm{R} / \mathrm{C}=1$ means the farming is break even

3. $\mathrm{R} / \mathrm{C}>1$ where the farming is efficient or feasible to be a farming business.

\section{RESULT AND DISCUSSION}

\section{Analysis of Production Cost, Revenue and Income of Pineapple Farming}

In carrying out the farming business is inseparable from the problem of cost and income. Figures referred to as costs in this case are all the value of the corporation of various inputs of production during the process takes place, the difference between the received anrata and the costs incurred in the call farm income.

\section{Production cost}

In every business activity in the field of agriculture will eventually be assessed the results to be obtained from the costs incurred during the production process takes place. Production costs are all expenditures expressed in the form of money during the production process to produce a product. In this analysis the cost of production is viewed from the point of the company, ie expenditure must be calculated as cost. Fixed costs are a small cost not dependent on the size of production, such as land taxes, land rent, depreciation of agricultural equipment and loan interest rates. Variable costs are costs that directly relate to the amount of production, such as expenditures for seeds, fertilizers, medicines and labor costs.

\section{Variable Cost}

Variable costs are costs that directly relate to the amount of production, such as expenditures for seeds, fertilizers, medicines and labor costs.

\section{Cost of Production means}

The use of these costs can be seen in table 1 below:

Table 1. Average use and incremental costs of production facilities

\begin{tabular}{|c|c|c|c|c|c|c|}
\hline \multirow{3}{*}{$\begin{array}{c}\text { Jenis Biaya } \\
\text { Sarana Produksi }\end{array}$} & \multicolumn{6}{|c|}{ Luas Lahan yang Dikelola } \\
\hline & \multicolumn{4}{|c|}{$0,5 \mathrm{Ha}$} & \multicolumn{2}{|c|}{$1 \mathrm{Ha}$} \\
\hline & Fisik (Kg) & $\begin{array}{l}\text { Harga } \\
\text { Satuan }\end{array}$ & $\begin{array}{l}\text { Nominal } \\
\text { (Rp) }\end{array}$ & Fisik (Kg) & $\begin{array}{l}\text { Harga } \\
\text { Satuan }\end{array}$ & $\begin{array}{l}\text { Nominal } \\
(\mathbf{R p})\end{array}$ \\
\hline Bibit Nanas & 35.000 & 250 & 8.750 .000 & 70.000 & 250 & 17.500 .000 \\
\hline Pupuk : & & & & & & \\
\hline - Organik & 2500 & 500 & 1.250 .000 & 5000 & 500 & 2.500 .000 \\
\hline - UREA & 525 & 1.900 & 997.500 & 1050 & 1.900 & 1.195 .000 \\
\hline - $\quad$ NPK & 225 & 2.400 & 540.000 & 450 & 2.400 & 1.080 .000 \\
\hline Pupuk Cair Amina & 35 Drum & 20.000 & 700.000 & 70 Drum & 20.000 & 1.400 .000 \\
\hline Ethrel & 18 botol & 35.000 & 630.000 & 35 botol & 35.000 & 1.225 .000 \\
\hline $\begin{array}{l}\text { Obat-obatan } \\
\text { Diazinon }\end{array}$ & 2 botol & 30.000 & 60.000 & 4 botol & 30.000 & 120.000 \\
\hline Jumlah & & & 12.927 .500 & & & 25.855 .000 \\
\hline
\end{tabular}


Price for pineapple seedlings Rp 250.00 / batang, for an area of 0.5 ha, organic fertilizer price Rp 500 / Kg, fertilizer price UREA Rp 1.900 / Kg, fertilizer price NPK Rp 2.400 / Kg, liquid fertilizer Rp 20.000 / drum, ethrel price Rp 35.000 / Kg and diazinon Rp 30.000 / Bottle.

From table 9 above can be seen the difference in the area of land used affects the production costs incurred. For a land area of $0.5 \mathrm{Ha}$ requires a production cost of $\mathrm{Rp} 12,927,500$ while for a land area of 1 ha requires a production cost of $\operatorname{Rp} 25,735,000$.

\section{Labor costs}

Labor costs are the costs incurred for the amount of labor used in farming. The manpower used in farming efforts includes both in-house and out-of-home workers comprised of men and women. Labor in the family is also calculated as labor. In the research area the wage sums for male laborers are $\mathrm{Rp} 25,000$, - and female laborers is $\mathrm{Rp} 18.000$, - For female laborers adjusted according to wage rate with Men's Working Day Unit (SHKP). A SHKP is equal to the length of working hours starting at 07.00-11.00 and 12.30-16.30 with a value of Rp 30.000, - The average use and cost of labor force that can be removed from farmers can be seen in the following table.

Table 2. Average labor cost by size of managed land

\begin{tabular}{|c|c|c|c|c|}
\hline \multirow[t]{2}{*}{ Jenis pekerjaaan } & \multicolumn{4}{|c|}{ Luas Lahan yang Dikelola } \\
\hline & \multicolumn{2}{|c|}{ Luas Lahan 0,5 Ha } & \multicolumn{2}{|c|}{ Luas Lahan 1 Ha } \\
\hline Kegiatan & $\begin{array}{c}\text { Fisik } \\
\text { (HKPS) }\end{array}$ & $\begin{array}{l}\text { Nilai } \\
\text { (Rp) }\end{array}$ & $\begin{array}{c}\text { Fisik } \\
\text { (HKPS) }\end{array}$ & $\begin{array}{l}\text { Nilai } \\
\text { (Rp) }\end{array}$ \\
\hline $\begin{array}{l}\text { Pengolahan Tanah dengan } \\
\text { traktor }\end{array}$ & 1 & 525.000 & 1 & 1.050 .000 \\
\hline Pemupukan awal & 6 & 180.000 & 15 & 450.000 \\
\hline Penanaman nanas & 25 & 750.000 & 50 & 1.500 .000 \\
\hline Pembungaan & 4 & 120.000 & 15 & 450.000 \\
\hline Pemupukan & 27 & 810.000 & 45 & 1.350 .000 \\
\hline Jumlah & 63 & 2.385 .000 & 126 & 4.800 .000 \\
\hline
\end{tabular}

From table 2 above it can be seen that the cost incurred for planting and fertilizing each planting season is greater, the cost incurred farmers with a land area of $0.5 \mathrm{Ha}$ as much as $\mathrm{Rp}$ 2.385.000, Sedangan farmers with a land area of $1 \mathrm{Ha}$ of $\mathrm{Rp} 4.800 .000$.

\section{Total Variable Cost}

The total variable cost is the variable cost amount used in the pineapple farm. The total cost of the variable is the amount of labor cost, the average of total variables issued by farmers can be seen in the following table.

Table 3. Average total variable cost by Area of Managed Land

\begin{tabular}{lll}
\hline \multicolumn{1}{c}{ Jenis Biaya } & \multicolumn{2}{c}{ Biaya pengelolaan Usahatani nanas } \\
\cline { 2 - 3 } & \multicolumn{1}{c}{ Luas Lahan 0,5 Ha } & \multicolumn{1}{c}{ Luas Lahan 1 Ha } \\
\hline Sarana Produksi & Rp 12.927 .000 & Rp 25.855 .000 \\
Tenaga Kerja & $\operatorname{Rp~} 2.385 .000$ & Rp 4.800.000 \\
\hline Jumlah & Rp $\mathbf{1 5 . 3 1 2 . 0 0 0}$ & Rp 30.655.000
\end{tabular}


JARES, Vol. 2 No. 2 September, 2017; p-ISSN: 2502-826X; e-ISSN: 2503-1163

Copyrights@ Balitar Islamic University, Blitar, Indonesia; Http://jares.unisbablitar.ejournal.web.id

Citation: Prayudhi, Luhur Aditya . 2017. Analysis of Farm in Pineapple (Ananas comulus (L.) Merr) in Sempu Village, District Ngancar, Kediri). JARES, (2017), 2(2): 10-18

From table 3 above can be seen that the total cost incurred in pineapple farming for farmers with a land area of $0.5 \mathrm{Ha}$ is as much as $\mathrm{Rp} 15.312 .000$, and farmers with a land area of 1 ha is as much as $\operatorname{Rp} 30.655 .000$.

\section{Fixed cost}

The cost of a starter is a type of cost that does not affect or determine the size of the production value is fixed costs in pineapple farming is the cost of land lease. The land managed from the sample farmers is self-owned land and some are rented. For land rent area of $1 \mathrm{Ha}$ is $\mathrm{Rp} 6,000,000$ / year while the land area of $0.5 \mathrm{Ha}$ is $\mathrm{Rp} 3,000,000$ / year. Land ownership status can be seen in tabe 11 below:

Table 4. Status of Land Ownership of Respondents

\begin{tabular}{lcc}
\hline \multicolumn{1}{c}{$\begin{array}{l}\text { Status Kepemilikan } \\
\text { Lahan }\end{array}$} & Luas $0,5 \mathrm{Ha}$ & Luas 1 Ha \\
\hline Milik Sendiri & 8 & 3 \\
Sewa & 7 & 2 \\
\hline Jumlah & 15 & 5
\end{tabular}

From table 4 above can be seen that the respondents with a land area of $0.5 \mathrm{Ha}$ who manages the land of his own as many as 8 People, 7 Others rent. While respondents with land area of 1 Ha own land ownership is 3 people, and 2 people rent land with an area of 1 ha. So it

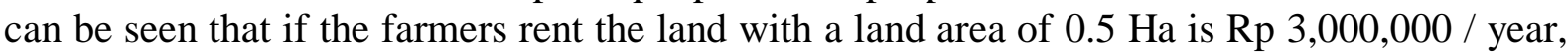
Rp 6,000,000 / year rent of land of $1 \mathrm{Ha}$.

\section{Capital Interest (cost of capital)}

The interest on pineapple farming is the cost incurred by the farmer, either the money owned by another person or his own, which is used in pineapple farming. The interest cost of capital is calculated based on the amount of money spent during the pineapple farm. In this study, the capital interest rate is calculated by multiplying the total use of money for 12 months with a percentage of $1.5 \%$.

From the calculation results obtained average capital interest rate of $\mathrm{Rp} 229,680$ for a land area of $0.5 \mathrm{Ha}$ and amounting to Rp 459,825 for an area of $1 \mathrm{Ha}$. The value of capital interest shows the difference, because the costs incurred by each land area are different.

\section{Fixed Cost}

The total fixed cost of the mina paddy business is the amount of fixed costs paid in the mina rice business. The total fixed cost is the total cost of renting the land, issued in the table presented in the following table.

Table 5. Average total fixed cost of each managed land

\begin{tabular}{lcc}
\hline \multirow{2}{*}{ Jenis Biaya } & \multicolumn{2}{c}{ Biaya Pengelolaan } \\
\cline { 2 - 3 } & Luas Lahan 0,5 Ha & Luas Lahan 1 Ha \\
\hline Sewa lahan & Rp 3.000.000 & Rp 6.000.000 \\
Bunga modal & Rp 229.680 & Rp 459.825 \\
\hline Jumlah & Rp 3.229.680 & Rp 6.459.825 \\
\hline
\end{tabular}

From the table above can be seen that the average total cost incurred in pineapple farming with a land area of $0.5 \mathrm{Ha}$ is $\mathrm{Rp} 3.229 .680$ and land with an area of 1 ha is $\mathrm{Rp} 6.459 .825$. 
JARES, Vol. 2 No. 2 September, 2017; p-ISSN: 2502-826X; e-ISSN: 2503-1163

Copyrights@ Balitar Islamic University, Blitar, Indonesia; Http://jares.unisbablitar.ejournal.web.id

Citation: Prayudhi, Luhur Aditya . 2017. Analysis of Farm in Pineapple (Ananas comulus (L.) Merr) in Sempu Village, District Ngancar, Kediri). JARES, (2017), 2(2): 10-18

\section{Total Production Cost}

The total cost of production in the mina paddy business is the total cost incurred for the mina paddy business that is the sum of the cost of production facilities, labor, land rent, capital cost and others. The average total production cost incurred by farmers is presented in the following table.

Table 6. Average total production cost by area Land managed

\begin{tabular}{|c|c|c|}
\hline Jenis Biaya & \multicolumn{2}{|c|}{ Luas Lahan } \\
\hline & $0,5 \mathrm{Ha}$ & $1 \mathrm{Ha}$ \\
\hline Saprodi & Rp 12.927.500 & $\operatorname{Rp} 25.855 .000$ \\
\hline Tenaga kerja & Rp 2.385.000 & $\operatorname{Rp} 4.800 .00$ \\
\hline Sewa lahan & Rp 3.000.000 & Rp 6.000.000 \\
\hline Bunga modal & Rp 229.680 & Rp 459.825 \\
\hline Jumlah & Rp 18.542.180 & Rp 37.114.825 \\
\hline
\end{tabular}

From the table above can be seen that the land area of 1 ha with production costs dbutuhkan pineapple farmers is as much as $\mathrm{Rp} 37.114 .825$, and the land area of $0.5 \mathrm{Ha}$ is as much as $\mathrm{Rp} 18,542,180$.

\section{Reception}

Revenue is the amount of money received by farmers from the production of the obtained production. So the revenue is the product of total production with the unit price. Production is the total result of the farm effort in the physical state. The sale of pineapple fruit brmacam-macam accordance with the quality of the fruit produced. Where the research in the sale of pineapple fruit is categorized by kuliatasnya. For A quality pineapple with price Rp 2.000 / buah, with production $25 \%$ from production fruit, quality B with production $30 \%$ with price Rp 1000 / fruit, and kulitas C produce 45\% with price Rp 300 / buah.Rata production and the total revenue received by farmers is presented in table 13 below:

Table 7. Average production and total revenue by managed Land Area

\begin{tabular}{crrrr}
\hline Kualitas & \multicolumn{2}{c}{ Luas Lahan 0,5 Ha } & \multicolumn{2}{c}{ Luas Lahan 1 Ha } \\
\cline { 2 - 5 } Nanas & Nilai (biji) & \multicolumn{1}{c}{ Nilai (Rp) } & Nilai (biji) & \multicolumn{1}{c}{ Nilai (Rp) } \\
\hline A & 8.750 & 17.500 .000 & 17.500 & 35.000 .000 \\
B & 10.500 & 10.500 .000 & 21.000 & 21.000 .000 \\
C & 15.750 & 4.725 .000 & 31.500 & 9.450 .000 \\
\hline JUMLAH & $\mathbf{3 5 . 0 0 0}$ & $\mathbf{3 2 . 7 2 5 . 0 0 0}$ & $\mathbf{7 0 . 0 0 0}$ & $\mathbf{6 5 . 4 5 0 . 0 0 0}$
\end{tabular}

The price of pineapple with A's more produces less production only about $25 \%$ of the number of seeds planted, but has a high selling price of $\mathrm{Rp} 2.000 /$ buah. While the quality of $\mathrm{C}$ is more producing $45 \%$ of the number of seeds planted. Quality $\mathrm{C}$ is meant here is a very low quality own more dn production with selling value is $\mathrm{Rp} 300$ / fruit. 
JARES, Vol. 2 No. 2 September, 2017; p-ISSN: 2502-826X; e-ISSN: 2503-1163

Copyrights@ Balitar Islamic University, Blitar, Indonesia; Http://jares.unisbablitar.ejournal.web.id

Citation: Prayudhi, Luhur Aditya . 2017. Analysis of Farm in Pineapple (Ananas comulus (L.) Merr) in Sempu Village, District Ngancar, Kediri). JARES, (2017), 2(2):10-18

\section{Income}

Revenue is the difference between total revenue and total production cost incurred during the production process of the pineapple farm. Here are the total revenue received by respondents:

Table 8 Total Revenues by Area of managed land

\begin{tabular}{cc}
\hline Luas Lahan & Rata-rata Pendapatan $(\mathrm{Rp})$ \\
\hline $0,5 \mathrm{Ha}$ & 14.182 .820 \\
$1 \mathrm{Ha}$ & 28.335 .175
\end{tabular}

In the above table it can be seen that the income of each land area is different. Farmer sample with land area 0.5 ha income from pineapple farming as much as Rp 14.182.820, while farmer of sample with land area 1 Ha profit equal to Rp 28.335.175.

\section{Financial Analysis}

\section{R / C Farmable Feasibility Test}

This efficiency analysis aims to determine whether the pineapple farming results are efficient or not, then between the analysis R / C Ratio (Return Cost Ratio), where R / C Ratio is the ratio between acceptance with production.

Table 9. R / C Ratio

\begin{tabular}{lcc}
\hline & \multicolumn{2}{c}{ Kelayakan Usahatani Nanas di Desa Sempu, Kec Ngancar } \\
\cline { 2 - 3 } R/C Ratio & 0.5 ha & 1 ha \\
\hline Total Penerimaan & $\mathbf{3 2 . 7 2 5 . 0 0 0}$ & $\mathbf{6 5 . 4 5 0 . 0 0 0}$ \\
Total Biaya & $\mathbf{1 8 . 5 4 2 . 1 8 0}$ & $\mathbf{3 7 . 1 1 4 . 8 2 5}$ \\
\hline TR/TC & $\mathbf{1 . 7 6 4 8}$ & $\mathbf{1 . 7 6 3 4}$ \\
\hline
\end{tabular}

The result of the business feasibility test of 0.5 ha and 1 ha is not the same for 0.5 ha yield 1.7648. $\mathrm{R} / \mathrm{C}$ ratio $>1$ which means pineapple farming at 0.5 ha is feasible to be developed and continued this every economic sacrifice Rp 1000 will generate Rp 1,764.8. As for the 1 ha $\mathrm{R} / \mathrm{C}$ ratio produces 1.7634 . $\mathrm{R} / \mathrm{C}$ ratio $>1$ which means pineapple farming on 1 ha is feasible to be developed, it is feasible because the result of $\mathrm{R} / \mathrm{C}$ ratio TR / TC $=1.7634$ which means every economic sacrifice of Rp. 1,000, - will earn Rp. 1,763.4, -. This is proof that farmers can not loose their attachment to the commodities of their farm products that have been able to sustain their economic life. For both patterns are equally good and worth developing.

\section{CONCLUSIONS AND RECOMMENDATIONS}

\section{Conclusion}

From the research results can be concluded:

1. For pineapple farming requires variable cost consisting of cost consumed (cost of seeds, medicines, flowering medicine (Ethrel), fertilizer) and labor cost (land processing, planting, fertilizing). Total cost variable for land area of $0.5 \mathrm{Ha} \mathrm{Rp} 15.312 .000$ and land area 1 Ha Rp 30.655.000.

2. For fixed cost of pineapple farming consist of land rent, capital interest can be known fixed cost for land area $0,5 \mathrm{Ha} \mathrm{Rp} 3,229,650$, land area $1 \mathrm{Ha} R \mathrm{Rp} 6,459,825$, hence can be calculated total cost in pineapple farm for land with an area of $0.5 \mathrm{Ha}$ of $\mathrm{Rp}$ $18,542,180$ and pineapple farming with an area of 1 ha of Rp 37.114.825. 
3. The sale results obtained by pineapple farmers selling price according to the quality of

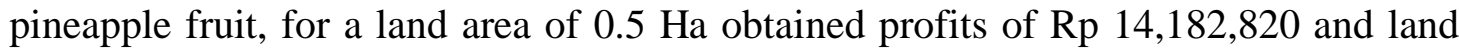
area of 1 Ha Rp 28.335.175.

4. The result of the business feasibility test of 0.5 ha and 1 ha is not the same for 0.5 ha yield 1.7648. While for 1 ha $\mathrm{R} / \mathrm{C}$ ratio produces 1.7634 . For both patterns are equally

\section{Suggestion} good and worth developing.

From the results of this study researchers can provide suggestions, namely:

1. To the Farmers

To increase farmer pineapple farming more aktf in the absorption of new technology. So farmers are expected to be more easily in the process of pineapple cultivation.

2. To the Government

- In order for the government to pursue capital for pineapple farming, and counseling is not limited to cultivation but also pineapple processing so that farmers can utilize their products so they can increase farmers' income.

- The government established a pineapple canning factory, because the district Ngancar District still no existing pineapple canning factory, so that pineapple marketing is still out of the District Ngancar.

\section{REFFERENCES}

Hermanto.2000. Tersedia pada www.wikimedia.com (diakses tanggal 5 Maret 2010).

Lisdina. 1997. Bertanam Nanas. Penebar Swadaya. Jakarta

Mubyarto. 2001. Analisis usahatani http:www.co.id. diakses pada 20 mei 2000.

Nakasone dan paul. 2001.Budidaya Nanas. Penerbit Gramedia Jakarta.

Rivai 1999 dalam soeharjo dan patoeng, 2000. Skripsi. Analisis Usahatani dan Pemasaran

Buah Nanas di Sumatera Utara. Fakultas Pertanian. Universitas Mataram

RUSNAS Pengembangan Buah Unggulan Indonesia, Database nanas www.Rusnasbuah.or.id

Soeharjo dan patoeng.2002. Sendi-sendi Pokok Usahatani.. jurusan Ilmu-Ilmu Sosial Ekonomi

Pertanian.. Institut Pertanian Bogor. Bogor

Soekartawi. 2000. Prinsip Dasar Ekonomi Pertanian. PT Raja Grafindo. Jakarta,

Soekartawi. 2001. Teori Ekonomi. PT Raja Grafindo. Jakarta.

Tjakrawilaksan A, 2001, Ilmu Usahatani . Ilmu-Ilmu social Ekonomi Pertanian. Fakultas

Pertanian. Institut Pertanian Bogor. Bogor.

Verheij dan coronel. 2000. Kamus Pertanian. Jakarta: Gramedia Widiasarana Indonesia

Warisno. 2000. Manfaat Buah-Buahan .Jakarta : Penebar Swadaya. 